\title{
The Step-type Contrast Structure for A Second Order Semi-linear Singularly Perturbed Differential-difference Equation
}

\author{
Mei $\mathrm{Xu}^{1}$ and Honghui Yin ${ }^{1}$ \\ ${ }^{1}$ Huaiyin Normal University
}

May 6, 2020

\begin{abstract}
The step-type contrast structure for a second order semi-linear singularly perturbed differential-difference equation is studied. Using the methods of boundary function and fractional steps, we construct the formula asymptotic expansion of the problem. At the same time, based on sewing techniques, the existence of the step-type contrast structure solution and the uniform validity of the asymptotic expansion are proved.
\end{abstract}

\section{Hosted file}

manuscript(1).pdf available at https://authorea.com/users/317553/articles/447615-thestep-type-contrast-structure-for-a-second-order-semi-linear-singularly-perturbeddifferential-difference-equation

\section{Hosted file}

manuscript(1).tex available at https://authorea.com/users/317553/articles/447615-thestep-type-contrast-structure-for-a-second-order-semi-linear-singularly-perturbeddifferential-difference-equation 